\title{
Motivational Factors Used to Stimulate the Creativity of Employees in Companies Operating in the Czech Republic
}

\author{
Miluše Balková ${ }^{1, *}$, Lenka Ližbětinová ${ }^{1}$ \\ ${ }^{1}$ Institute of Technology and Business, Faculty of Corporate Strategy, Okružní 517/10, 37001 Česke Budějovice, Czech Republic
}

\begin{abstract}
Current circumstances are forcing companies to react quickly to the changes that are taking place. Maintaining competitiveness and survival depends on adaptability and the search for innovations. The goal of modern human resource management is to stimulate employees to be creative and utilise their potential. The aim of this study is to find out what motivational factors Czech companies use to stimulate and encourage the creativity of their employees and whether the chosen factors for achieving this are related to company size.
\end{abstract}

Keywords: creativity; management; employees; motivation; HRM

\section{Introduction}

In today's globalized world, businesses are increasingly exposed to turbulent change, which places high demands on the ability to adapt quickly and innovate. This process can either generate opportunities for business success, or pose a huge threat to a business' very existence [1]. The ability to respond correctly to market changes depends on, among other things, a company's know-how and the creativity of its human resources. The originality of the ideas that people in a company are able to generate differentiates a company's products or services from those of its competitors. Supporting and using creativity in a company is therefore becoming a great challenge for managers at all levels.

The key drivers of competitive advantage are inimitable intangible resources [2], such as a company's ability to foster innovation and creativity $[3,4,5]$. The prerequisite is an emphasis on supporting the creativity of employees and setting up a management system that utilizes the internal motivation of employees. The art of offering innovative products needs creative employees who are stimulated to develop their creative potential and generate creative ideas. Ideas are subsequently a source of innovation and competitive advantage [6]. Within industry, there are sectors which, by their very nature, require a high level of creativity from their employees (creative industries), while in other industries, employee creativity is not much required ("non-creative" sectors) and the fulfilment of mere tasks is expected. Due to the different work requirements, the management systems in the two groups differ greatly [7]. Industry 4.0 is changing approaches to human resource management, whereby creativity is becoming a key element [8,9].

The aim of this study is to determine what motivational factors Czech companies apply to stimulate the creativity of their employees and whether this is related to company size.

\section{Concepts and Basic Theories}

Employee creativity is a key factor in a company's success. In their analytical study, Purdenko et al. [10] state that under modern market conditions, companies can increase their level of competitiveness through the implementation of policies that support their employees' creative activity, and that in doing so it will increase the effectiveness of the creative management system of the company as a whole.

In studies, a creative personality is associated with such traits as independence, entrepreneurship, radicality, openness to experience [11]. According to Fedor [12], there is a relationship between creativity, values, personality traits and conflicting personality behaviours. A positive correlation is observed with the values of independence and success and with the values of modesty and conformism. Creativity is also positively associated with strategies for managing decisionmaking, taking responsibility and distancing; influence - seek social support, remove obligations and reassessment [12, $13,14]$.

The creative behaviour of employees significantly influences the approach of a superior employee. The results of a questionnaire survey conducted by Nazir et al. [15] show that authoritarian leadership has an effective impact on the

\footnotetext{
* Corresponding author: balkovam@mail.vstecb.cz
} 
creative behaviour of workers. To stimulate innovation [16], managers should provide employees with a safe workplace environment in which they can safely take risks and show creativity, which ultimately contributes to increasing employee and organizational performance [15].

Al-Tit et al. [17] conducted a questionnaire survey of industrial companies and, based on the analysis of responses, concluded that employee pro-activity is a function of three categories of HR practices. First, the employee should be supported to improve their skills. Second, the employee should be motivated and given the opportunity to share knowledge. Third, employees should be encouraged to participate in problem-solving in the presence of the lead manager, in order to improve the quality of relationships and to recognize team members, their support and effective communication [17]. According to Henri [18], there are two ways in which creative employees can be stimulated in a company. This includes the creation of working conditions [19] for creativity and the opportunity to become a leader in the field. The author mostly talks about specialists who can draw on their deep knowledge and further develop it. This statement is deduced from the trend of today's innovative economy, which forces individuals to produce something new all the time.

Madjar et al. [20], on the basis of questionnaires and interviews, examined the relationship between creative performance and the extent to which employees received support for creativity from both work (supervisors/co-workers) and non-work (family/friendly) sources. The results showed that the support of both work and non-work sources significantly and independently contribute to creative performance. These relationships create a positive mood, whereby employees with less creative personalities respond the most positively to support from non-work sources [20].

A lot of research has been conducted into identifying the factors that lead to a creative outcome, but little that leads employees to start the creative process. This issue was addressed by Unsworth et al. [21], who used semi-structured interviews to explore the factors and processes that are involved in this phenomenon. They found that general work motivation, creativity requirements, cultural support for creativity, time resources and independence are among the stimuli that determine whether an event creator pays off. Dul et al. [22] also confirm that a creative work environment encourages creative performance. Gong et al. [23] state that employees' creativity is positively linked to further training opportunities as well as the appraisal of their performance [24].

This study uses the responses to a questionnaire survey to determine the relationship between company size and the selected motivational factors for stimulating and supporting employee creativity. The research questions were formulated as follows: What motivational factors are most often applied to stimulate the creativity of employees? Are the selected motivational factors for stimulating employee creativity related to company size?

\section{Methodology}

To fulfil the aim of the study, a questionnaire survey was conducted among 372 Czech companies to determine what motivational factors they apply to stimulate and support the creativity of employees. The questionnaire was addressed to HR professionals. A stratified random selection according to company size and regional location was used to create the basic sample (return rate of questionnaires was 54\%). The company size was determined through the questionnaire, and the individual motivational factors evaluated on the basis of a 5-point scale, whereby $1=$ we do not apply it and $5=$ we apply it in full (see Table 1).

Table 1. Evaluation scale

\begin{tabular}{|l|c|c|c|c|c|}
\hline \multicolumn{7}{|l|}{ Evaluation scale } & $\bullet \mathbf{1}$ & $\mathbf{2}$ & $\mathbf{3}$ & $\mathbf{4}$ & $\mathbf{5} \odot$ \\
\hline $\begin{array}{l}\text { Application in } \\
\text { the company }\end{array}$ & $\begin{array}{c}\text { We do not } \\
\text { apply it }\end{array}$ & $\begin{array}{c}\text { We do not apply it } \\
\text { yet, but are } \\
\text { considering doing } \\
\text { so }\end{array}$ & $\begin{array}{c}\text { I cannot } \\
\text { assess the } \\
\text { actual } \\
\text { situation }\end{array}$ & $\begin{array}{c}\text { We } \\
\text { partially } \\
\text { apply it }\end{array}$ & $\begin{array}{c}\text { We } \\
\text { apply it } \\
\text { in full }\end{array}$ \\
\hline
\end{tabular}

Source: Authors.

The assessed motivational factors that are considered important for the stimulation of creativity in a company were: A1 - meaningfulness of work (employees know the meaning of their work); A2 - involvement (giving space to assert oneself); A3 - enthusiasm (shared interest and enjoyment of work); A4 - cooperation; A5 - recognition (public, personal); A6 - open communication; A7 - support; A8 - autonomy; A9 - emphasis on health; A10 - trust; A11 - responsibility (inner sense of responsibility). The responses were analysed using SPSS Statistics 26. First, the companies were divided according to size, then the average assigned values for the individual motivational factors were calculated according to the size of the company. Finally, an ANOVA test was performed at a significance level of 5\%.

\section{Results and Discussion}

The companies that took part in the research were of varying sizes, of which $31.2 \%$ were large companies, $26 \%$ were medium-sized companies, $25 \%$ were small companies, and $17.7 \%$ were micro-companies (see Table 2). 
Table 2. Structure of the research sample

\begin{tabular}{|c|c|c|c|c|}
\hline Company size & Frequency & \% & Valid \% & Cumulative \% \\
\hline Micro- & 66 & 17.7 & 17.7 & 17.7 \\
\hline Small & 93 & 25.0 & 25.0 & 42.7 \\
\hline Medium-sized & 97 & 26.1 & 26.1 & 68.8 \\
\hline Large & 116 & 31.2 & 31.2 & 100.0 \\
\hline Total & $\mathbf{3 7 2}$ & $\mathbf{1 0 0 . 0}$ & $\mathbf{1 0 0 . 0}$ & \\
\hline
\end{tabular}

Source: Authors.

Based on the average values assigned by the HR professionals according to the evaluation scale, the most used motivational factor is meaningfulness of work. However, this is, on average, only partially applied (value 4.21). The second most frequently partially applied motivational factor is emphasis on health (value 4.14). Motivation through cooperation (value 3.98) and responsibility (value 3.97) were also allocated significant values. Unfortunately, most respondents could not assess the current situation with regards to the application of the identified motivational factors in their company (see Table 3). According to the results, it can be deduced that in order to stimulate creativity, Czech companies believe they must set common goals, the achievement of which is a shared responsibility, and place emphasis on health and a safe workplace environment. However, research shows that creativity is significantly motivated by independence, recognition of performance and enjoyment of work [11], which is an approach that is less widely applied in the Czech Republic. The reason for this is historical, in the sense that people in the Czech Republic were educated for almost fifty years to live in groups (especially in school and work). This finding could be another subject of research.

Table 3. Arithmetic averages for the identified motivational factors by company size

\begin{tabular}{|c|c|c|c|c|c|c|c|c|c|c|c|}
\hline $\begin{array}{c}\text { Motivational factor/ } \\
\text { Company size }\end{array}$ & $\mathbf{A 1}$ & $\mathbf{A 2}$ & $\mathbf{A 3}$ & $\mathbf{A 4}$ & $\mathbf{A 5}$ & $\mathbf{A 6}$ & $\mathbf{A 7}$ & $\mathbf{A 8}$ & $\mathbf{A 9}$ & $\mathbf{A 1 0}$ & $\mathbf{A 1 1}$ \\
\hline Micro- & 4.21 & 3.70 & 3.35 & 4.02 & 3.61 & 3.65 & 3.74 & 3.58 & 4.26 & 4.03 & 4.02 \\
\hline Small & 4.25 & 3.67 & 3.45 & 4.06 & 3.67 & 3.85 & 3.78 & 3.53 & 4.34 & 3.92 & 3.85 \\
\hline Medium-sized & 4.31 & 3.57 & 3.43 & 3.94 & 3.51 & 3.76 & 3.78 & 3.46 & 4.06 & 3.85 & 4.12 \\
\hline Large & 4.09 & 3.69 & 3.38 & 3.93 & 3.35 & 3.66 & 3.63 & 3.46 & 3.97 & 3.74 & 3.91 \\
\hline Total & $\mathbf{4 . 2 1}$ & $\mathbf{3 . 6 5}$ & $\mathbf{3 . 4 1}$ & $\mathbf{3 . 9 8}$ & $\mathbf{3 . 5 2}$ & $\mathbf{3 . 7 3}$ & $\mathbf{3 . 7 3}$ & $\mathbf{3 . 5 0}$ & $\mathbf{4 . 1 4}$ & $\mathbf{3 . 8 7}$ & $\mathbf{3 . 9 7}$ \\
\hline
\end{tabular}

Source: Authors.

The data (see Table 4) from the ANOVA test (at a significance level of 5\%) proved that company size has a statistically significant effect on the emphasis on health ( $p$-value 0.012). The relationship between company size and the other motivational factors proved to be insignificant (see Table 4). From Table 3 follows, that as company size grows the application of motivational factors becomes statistically less significant. The greater frequency with which the selected motivational factors are applied in micro- and small companies corresponds more to the individual work performance required of employees and the achievement of common goals than the average. This creates more space for the utilization of the creativity of individual employees. In contrast, HR professionals in large companies are losing the ability to assess whether these motivations factors are actually applied.

Table 4. ANOVA test results for motivational factors by company size

\begin{tabular}{|c|c|c|c|c|c|c|}
\hline \multicolumn{7}{|c|}{ ANOVA test } \\
\hline \multicolumn{2}{|c|}{ Dependent variable } & Sum of Squares & Df & Mean Square & F & P-value \\
\hline \multirow{3}{*}{$\begin{array}{c}\text { A1 Meaningfulness of } \\
\text { work }\end{array}$} & Between Groups & 2.624 & 3 & 0.875 & 1.171 & 0.321 \\
\hline & Within Groups & 275.021 & 368 & 0.747 & & \\
\hline & Total & 277.645 & 371 & & & \\
\hline \multirow{3}{*}{ A2 Involvement } & Between Groups & 1.018 & 3 & 0.339 & 0.432 & 0.730 \\
\hline & Within Groups & 289.248 & 368 & 0.786 & & \\
\hline & Total & 290.266 & 371 & & & \\
\hline \multirow{3}{*}{ A3 Enthusiasm } & Between Groups & 0.565 & 3 & 0.188 & 0.183 & 0.908 \\
\hline & Within Groups & 379.142 & 368 & 1.030 & & \\
\hline & Total & 379.707 & 371 & & & \\
\hline \multirow{3}{*}{ A4 Cooperation } & Between Groups & 1.193 & 3 & 0.398 & 0.439 & 0.725 \\
\hline & Within Groups & 333.675 & 368 & 0.907 & & \\
\hline & Total & 334.868 & 371 & & & \\
\hline \multirow{3}{*}{ A5 Recognition } & Between Groups & 5.723 & 3 & 1.908 & 1.795 & 0.148 \\
\hline & Within Groups & 391.180 & 368 & 1.063 & & \\
\hline & Total & 396.903 & 371 & & & \\
\hline \multirow{3}{*}{$\begin{array}{c}\text { A6 Open } \\
\text { communication }\end{array}$} & Between Groups & 2.488 & 3 & 0.829 & 0.762 & 0.516 \\
\hline & Within Groups & 400.631 & 368 & 1.089 & & \\
\hline & Total & 403.118 & 371 & & & \\
\hline \multirow[t]{2}{*}{ A7 Support } & Between Groups & 1.744 & 3 & 0.581 & 0.637 & 0.592 \\
\hline & Within Groups & 335.834 & 368 & 0.913 & & \\
\hline
\end{tabular}




\begin{tabular}{|c|c|c|c|c|c|c|}
\hline & Total & 337.578 & 371 & & & \\
\hline \multirow{3}{*}{ A8 Autonomy } & Between Groups & 0.785 & 3 & 0.262 & 0.270 & 0.847 \\
\cline { 2 - 7 } & Within Groups & 356.212 & 368 & 0.968 & & \\
\cline { 2 - 7 } & Total & 356.997 & 371 & & & \\
\hline \multirow{2}{*}{$\begin{array}{c}\text { A9 Emphasis on } \\
\text { health }\end{array}$} & Between Groups & 8.569 & 3 & 2.856 & 2.751 & $\mathbf{0 . 0 4 3}$ \\
\cline { 2 - 7 } & Within Groups & 382.162 & 368 & 1.038 & & \\
\cline { 2 - 7 } & Total & 390.731 & 371 & & & \\
\hline \multirow{2}{*}{$\begin{array}{c}\text { A10 Trust } \\
\text { A11 Responsibility }\end{array}$} & Between Groups & 3.945 & 3 & 1.315 & 1.385 & 0.247 \\
\cline { 2 - 7 } & Within Groups & 349.334 & 368 & 0.949 & & \\
\cline { 2 - 7 } & Total & 353.280 & 371 & & & \\
\cline { 2 - 7 } & Wetween Groups & 4.144 & 3 & 1.381 & 1.467 & 0.223 \\
\cline { 2 - 7 } & Within Groups & 346.531 & 368 & 0.942 & & \\
\hline
\end{tabular}

Note: bold highlights statistically significant results at a significance level of 5\%

Source: Authors.

\section{Conclusion}

In Czech companies, the motivational factors meaningfulness of work and emphasis on health are the most frequently used to stimulate the creativity of employees, as are cooperation and responsibility - an inner sense of responsibility. According to the results, it can be deduced that in order to stimulate creativity, Czech companies believe employees must work in a team with set common goals, the achievement of which is a shared responsibility, and place emphasis on health and a safe workplace environment. Unfortunately, although research shows that creativity is significantly motivated by independence, recognition of performance and enjoyment of work, none of the respondents felt they could evaluate the situation in their company, which is reflected in the fact that this approach is less widely applied in the Czech Republic. Company size has a statistically significant effect on the emphasis on health. As company size grows, the application of these motivational factors decreases. Micro- and small companies seemingly make more use of individual performance incentives within the context of achieving common goals than the average. The greater ability to apply these motivational factors suggests a better ability to use the creative potential of individual employees compared to large companies where HR professionals seem to lose track of the motivational factors they actually apply.

The preference for collective motivation over individual motivation in Czech companies could be the subject of further research.

\section{References}

1. S. Cardinaleschi, M. Damiani, F. Pompei, Knowledge-intensive sectors and the role of collective performancerelated pay. Industry and Innovation. 27(5), 480-512 (2020)

2. J. Hyršlová, J. Chocholac, D. Sommerauerová, P. Štěpán. Sustainability and transport construction companies. International Days of Statistics and Economics 2019 (2019)

3. R. K. Scott, Creative Employees: A Challenge to Managers. Journal of Creative Behavior. 29(1), 64-71 (1995)

4. H.-J. Cho, V. Pucik, Relationship between innovativeness, quality, growth, profitability and market value. Strategic Management Journal. 26(6), 555-575 (2005)

5. J. Poór, A. D. Engle, Á. Kovács, A. Albrychiewicz-Slocinska, Z. Caha, V. Kumpikaite-Valiuniene, Z. Horbulák, Initial Findings for Labour Markets in the Czech Republic, Hungary, Poland and Slovakia. Central European Journal of Labour Law Personnel Management. 3(1), 47-60 (2020)

6. S. Jovčić, P. Pruša, M. Dobrodolac, L. Švadlenka, A proposal for a decision-making tool in third-party logistics (3PL) provider selection based on multi-criteria analysis and the fuzzy approach. Sustainability. 11(15) (2019)

7. I. Grabner, Managing Organizational Creativity Motivational aspects of management control systems for creative employees. Wien: Wirtschaftsuniversität Wien. (2007)

8. A. Kucharčíková, M. Mičiak, M. Hitka, Evaluating the effectiveness of investment in human capital in e-business enterprise in the context of sustainability. Sustainability. 10(9) (2018)

9. D. Jašková, Assessment of Social Development in Slovakia in the Context of Human Resources. Central European Journal of Labour Law Personnel Management. 2(2), 21-32 (2019)

10. E. Purdenko, O. Matusova, V. Andryeyeva, Assessment of Employees' Creative Activity in Modern Conditions of Intellectualization of the Economy. Baltic Journal of Economic Studies. 5(1), 182 (2019) 
11. B. Barbot, M. Besancon, T. Lubart, Creative Potential in educational settings: Its natuer measure, and Nurture. Education 3-13. 43(4), 1-11 (2015)

12. A. Fedorova, The Connection Between Worker's Creativity, Values and Conflict Behavior. Psychology. Journal of Higher School of Economics. 16(1), 191-203 (2019)

13. E. Nedeliakova, M. Panak, J. Ponicki, R. Sousek, Progressive Management Tools for Quality Improvement. In: International Conference on Engineering Science and Management, 195-198 (2016)

14. M. Uhlerová, The Role of Trade Unions and Social Dialogue During the Crisis: the Case of Slovakia. Central European Journal of Labour Law Personnel Management. 3(1), 61-76 (2020)

15. S. Nazir, A. Shafi, M. A. Asadullah, W. Qun, S. Khadim, Linking paternalistic leadership to follower's innovative work behavior: the influence of leader-member exchange and employee voice. European Journal of Innovation Management (2020)

16. S. Lorincová, J. Schmidtová, J. Javorcíková, The impact of the working position on the level of employee motivation in Slovak furniture companies. Acta Faculatis Xylologiae. 60(2), 211-223 (2018)

17. A. A. Al-Tit, The impact of AMO-HR systems on proactive employee behavior: The mediating contribution of leader-member and team-member exchange. International Journal of Engineering Business Management. 12, 1-13 (2020)

18. J.-F. Henri, Organizational culture and performance measurement systems. Accounting Organizations and Society. 31(1), 77-103 (2006)

19. S. Lorincová, K. Stachová, Z. Stacho, Z. Joniaková, Defining the differences in corporate culture in wood-processing and forest enterprises. Bioresources. 15(2), 3320-3343 (2020)

20. N. Madjar, G. R. Oldham, M. G. Pratt, There's No Place like Home? The Contributions of Work and Nonwork Creativity Support to Employees' Creative Performance. The Academy of Management Journal. 45(4), 757-767 (2002)

21. K. L. Unsworth, C. W. Clegg, Why do employees undertake creative action? Journal of Occupational and Organizational Psychology. 83(1), 77-99 (2010)

22. J. Dul, C. Ceylan, Work environments for employee creativity.” Ergonomics. 54(1), 12-20 (2011)

23. Y. Gong, Employee learning orientation, transformational leadership and employee creativity: The mediating role of employee creative self-efficacy. Development and Learning in Organizations. 24(2), 366-372 (2010)

24. L. Mura, B. Gontkovicova, E. D. Spisakova, Z. Hajduova, Position of employee benefits in remuneration structure. Transformations in Business and Economics. 18(2), 156-173 (2019) 